\title{
GOVERNMENT REGULATION AND CONSUMER EVALUATION AFTER DAIRY PRODUCTS SCANDAL IN CHINA
}

\author{
Y. SHAO ${ }^{\mathrm{a}}$, G. CHEN ${ }^{\mathrm{b}}, \mathrm{R} . \mathrm{LI}^{\mathrm{c}}$ and F. $\mathrm{LIU}^{\mathrm{c}}$ \\ ${ }^{\mathrm{a}}$ China Institute of Regulation Research, ${ }^{\mathrm{b}}$ School of Economics, ${ }^{\mathrm{c}}$ School of Accounting, Zhejiang University \\ of Finance and Economics, Xueyuan street, Hangzhou 310018. China
}

(Received: 14 September 2019; accepted: 5 November 2019)

With the continuous expansion of the global dairy trade market, the quality and safety of the Chinese dairy market have a wide and far-reaching impact on the world. Based on the development of the dairy scandal in the past few years in China, this study illustrates the serious damage of melamine on human health and the negative impact on the dairy industry in China.

This study shows that the lack of effective government regulations is a key reason for dairy market failure. Consumers are lacking confidence in the quality of Chinese dairy products and the government's market regulations. The Chinese dairy market will continue to rely on imported dairy products. By analyzing the typical cases of the dairy market in China, this study aims to provide a guide for dairy industries in other countries.

Keywords: dairy products, scandal, melamine, government regulation, consumer evaluation, China

In recent years, food safety has attracted great concern all over the world. According to the World Health Organization report on foodborne diseases, 600 million people worldwide suffer from foodborne diseases and 420000 people die each year; therefore, food safety requires the prevention of foodborne disease through safety assessment of food products, components and manufacturing practices for both microbiological and chemical contaminants (CULLOR, 1997). The global connectivity and network asymmetry make the governance of the global food system complex. Poor policy responses in one area can have global effects, for example the catastrophic food safety incidents in China (SHao, 2013; SHAo \& CAI, 2016). Causal and substantive linkages exist between food security and violent conflict, spanning the individual up to global levels (Martin-Shields \& Stojetz, 2019). In a word, social stability can be reserved if a healthy food safety environment can be provided and sustained.

Dairy products are an important way for human beings to obtain nutrients. Dairy derived foods are a nutritious source of proteins, fats, micronutrients, prebiotics, and probiotics, which can contribute significantly to food security and human health (HopPE et al., 2006). Consumption of dairy products has a positive impact on bone mass, cardiovascular health, and the gastrointestinal microbiome (MAJOR et al., 2008). Dairy products are also an important source of high-quality animal proteins in developing countries. Increased consumption of these products by pregnant women and young children is advocated to reduce malnutrition and child stunting (HAVELAAR et al., 2019).

China has the largest consumption of dairy products and plays a prominent role in the global dairy trade market. Therefore, the quality and safety of China's dairy market is particularly important. Ironically, melamine received public and regulatory attention in 2008

* To whom correspondence should be addressed.
Phone: +86-18957125953; fax: +86-0571-87557100; e-mail: shaoyitian8888@163.com 
due to a scandal in China that involved the adulteration of milk and infant formula, which affected tens of thousands of infants (ZHU \& KanNan, 2019). A similar incident took place in 2007 in the United States, when melamine adulteration of pet food resulted in many deaths of cats and dogs (Brown et al., 2007).

\section{Materials and methods}

The main data source of this paper includes the following aspects:

a) Import and export data of Chinese dairy products from 2000 to 2016 (FAO, 2019).

b) The data of milk and dairy production in China from 2000 to 2017 (Dairy Association of China, 2018).

c) Current hygienic standard of milk in China (National Standards of the People's Republic of China, 2010).

d) The data of national consumer satisfaction from 2010 to 2016 (China Association for Quality, 2019).

This paper mainly collects the data related to Chinese dairy products on various authoritative official websites, and refers to a large number of references.

\section{Results and discussions}

\subsection{A review on the dairy products scandal}

In 2008, there was a shocking dairy scandal in China, where melamine was artificially mixed into milk to increase the nitrogen content and make the protein content up to the prescribed standard. Melamine milk came mainly from Sanlu co. Ltd, which was the largest milk manufacturer at that time in China, but it was not the only company involved (SCHODER \& MCCULLOCH, 2019). There were about 22 dairy brands implicated (INGELFINGER, 2008). More than 50,000 children had been hospitalized and at least six had died in China as a result of the melamine milk incident. The incident expanded to include children in Singapore and Vietnam. Babies and infants are most susceptible to melamine toxicity, by the formation of urinary tract concretions, which are difficult to diagnose, but potentially fatal (SCHODER \& MCCULLOCH, 2019). The main process of artificially adding melamine to dairy products is shown in Fig.1.

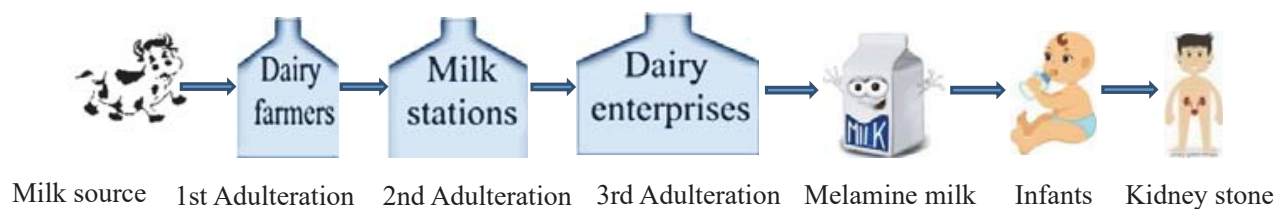

Fig.1. Main process of artificially adding melamine to dairy products

\subsection{Reasons for adding melamine to dairy products}

Melamine (1,3,5-triazine-2,4,6-triamine, or C3H6N6) is widely used in various fields such as plastics, adhesives, glues, and laminated products (InGELFINGER, 2008). The rich urea resources allow China to have advantages in the production of melamine. Melamine is 
derived from urea $\left(\left(\mathrm{NH}_{2}\right)_{2} \mathrm{CO}\right)$ through decomposition to cyanic acid (HCNO) and polymerization to melamine.

$$
6\left(\mathrm{NH}_{2}\right)_{2} \mathrm{CO} \rightarrow 6 \mathrm{HCNO}+6 \mathrm{NH}_{3} \rightarrow \mathrm{C}_{3} \mathrm{H}_{6} \mathrm{~N}_{6}+3 \mathrm{CO}_{2}+6 \mathrm{NH}_{3}
$$

It is often necessary to check the protein content in the food industry, but the measurement is complex and costly. Therefore, Kjeldahl nitrogen determination is often used to calculate the protein content indirectly. The fact that melamine could increase the apparent protein content and, furthermore, make the product look milky, may have been irresistible to those who would adulterate (INGELFINGER, 2008).

\subsection{Mechanism of melamine poisoning}

The toxicity of melamine caught the attention of researchers. A variety of toxic effects from melamine, including nephrolithiasis, chronic kidney inflammation, and bladder carcinoma, all have been studied in animals (HAU et al., 2009). Melamine deposition then leads to crystallisation when the urine is saturated. The crystals can also lead to stone formation, or mucosal ulceration and inflammation, and tumour in the long run (Wong \& CHIU, 2008). The combination of melamine and cyanuric acid is responsible for acute renal failure in cats (Puschner et al., 2007).

\subsection{Analysis of situation of Chinese dairy products on the market}

2.4.1. Domestic dairy production. The 2008 dairy scandal was set as midpoint, then the changes in dairy production in China from 2000 to 2017 were analyzed. According to the data from the China dairy yearbook 2017, the average annual growth rates of milk production were $20 \%$ (2000-2008) and $-0.03 \%$ (2008-2017); the average annual growth rates of dairy production were $31 \%(2000-2008)$ and 5.5\% (2008-2017). The results show that dairy production increased rapidly before 2008, while stopped growing after 2008.

2.4.2. Long-term deficit in dairy trade. The following are statistics from the Food and Agriculture Organization of the United Nations. The data contains the following seven types of dairy products: whole fresh cow, whole evaporated, whole dried, whole condensed, skimmed dried, skimmed cow milks and products of natural constituents. The quantity and value of imports and exports in China are shown in Figure 2. Obviously, 2008 was the beginning of the import and export extremes of dairy products. The average price of imported dairy products has a clear advantage since 2013. The purchase price of Chinese raw milk was 46 percent higher than of the United States, 62 percent higher than of Germany and 114 percent higher than of New Zealand in 2016 (CHANGQUAN et al., 2018). High prices and poor reputation put Chinese dairy in a difficult position. According to a research study, when consumers choose to purchase unfamiliar foreign products, they often infer the relevant attributes of the products from the information of the source country of the products, and this then affects their attitude towards the products (SCHNETTLER et al., 2008).

\subsection{Regulations and hygienic standards}

The melamine dairy scandal has attracted close attention of the Chinese government, and relevant regulatory departments at all levels have taken a series of urgent measures to rectify China's dairy industry in an all-round way. However, law enforcement standards are not highly consistent due to multi-departmental co-management. Therefore, there may be a blank 
area for law enforcement. In addition, many laws and regulations are promulgated after the outbreak of food safety incidents and early warning and prevention mechanisms are inefficient.
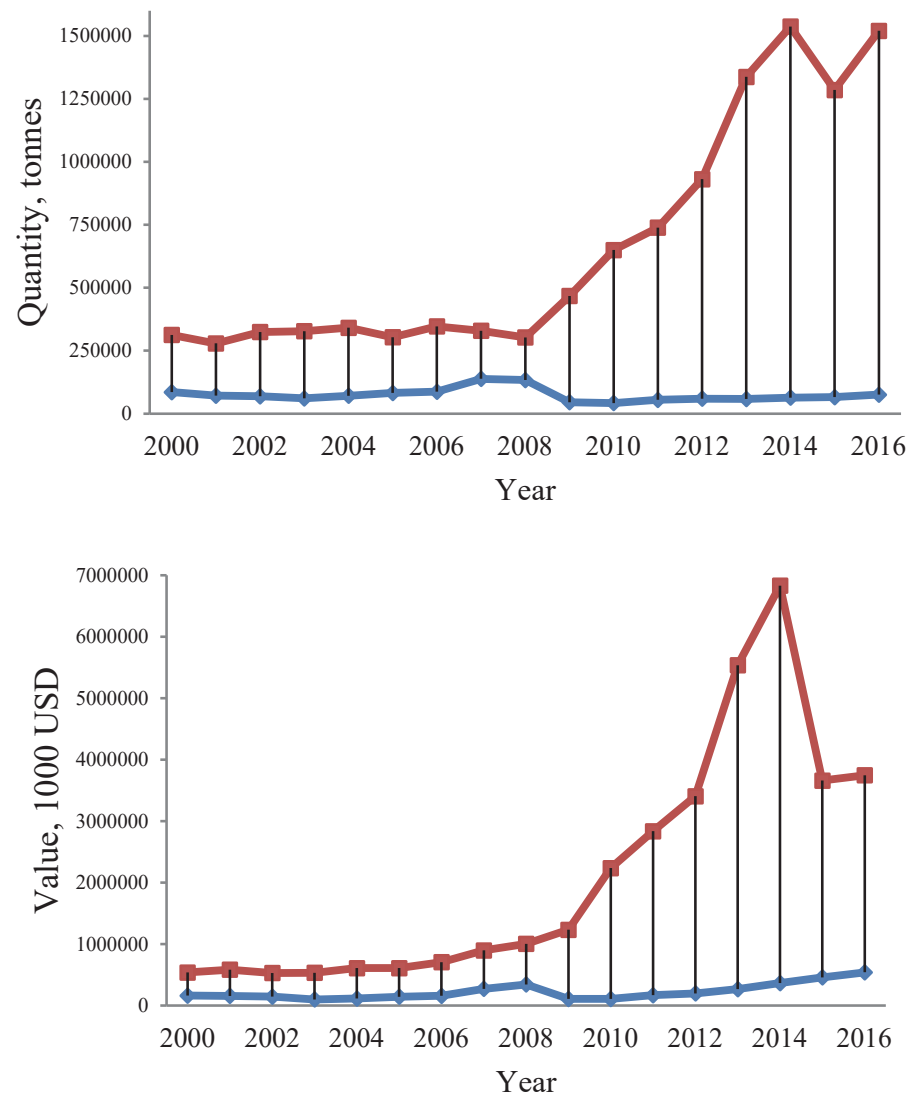

Fig. 2. Comparison of import and export quantity and value of dairy products $\longrightarrow$ :xport; $\because$ Import

China should continue to improve the corresponding laws and regulations. Regulatory experience should be learned from developed countries such as the United States to achieve effective supervision. Compared with other countries, the hygienic standards of dairy products are looser in China. Standards show that the total number of bacteria is 5 times higher than in the USA (A Grade), $\mathrm{Pb}$ is 2.5 times higher than in other countries such as Australia, New Zealand, Canada, and USA.

\subsection{Invalid regulation leads to market failure}

Government regulation is a restriction imposed by the government on economic activities with legitimate rights. The purpose of government regulation is to make corresponding rules for market operation and enterprise behaviour, and to maximize social welfare. WP Zhang, a professor at Tsinghua University, said that "The dairy scandal shows that some local 
governments and enterprises are not really separated in China, and government functions need to be completely transformed". The ongoing problems caused by melamine contamination are also linked to the rapid and unregulated development of dairy enterprises (PEI et al., 2011).

In asymmetric information markets, consumers often rely on certain extrinsic indictors to assess the safety of food products. In the melamine dairy scandal, consumers were completely unaware of the dairy quality, while dairy farmers, milk stations, and dairy enterprises had formed subconscious cooperation. The information of the buyers and sellers is in a state of complete asymmetry.

\subsection{Consumer evaluation}

2.7.1. Consumer evaluation of dairy products. China Association for Quality organized a national consumer satisfaction survey for the liquid milk industry. The satisfaction degrees were 72\% (2010), 76\% (2011), 76\% (2012), 75\% (2013), 76\% (2014), 77\% (2015), and 76\% (2016). The average satisfaction degree was $75.4 \%$. The results show that consumers were not satisfied with the quality of domestic liquid milk. A similar study showed that a higher satisfaction leads to greater levels of loyalty and buying intention of olive oil (EsPEJEL et al., 2008)

Chinese Nutrition Society published dairy consumption network survey data in 2017, the results show that brand and consumption concept have a certain impact on purchase choices, 36 percent of consumers were willing to pay higher prices for better foreign brands. The results also show that consumption factors of dairy products were safety $(70.2 \%)$, nutrition $(61.5 \%)$, brand $(51.6 \%)$, mouth-feel $(45 \%)$, price $(32.3 \%)$, health care function (20.3\%), and packaging appearance (6.4\%). $80.51 \%$ of consumers were concerned about the production date and shelf life of dairy products. This data illustrates that consumers were more aware of health and more concerned about food safety. The results are in good agreement with findings of GRUNERT (2005) that quality and safety perception is linked to food choice and consumer demand.

2.7.2. Consumer evaluation of government regulation. The government supervision system plays a command and control role to enforce good quality of dairy products and a safe environment. Government regulation through norms and standards is one of the factors stimulating innovation (BEEREPOOT \& BEEREPOOT, 2007). The overall thrust of these types of regulations is to ensure market stability and maintenance of appropriate control in certain areas of the economy (LEMAIRE, 2017).

Consumers evaluate the perceived trust in the government in the aspects of regulatory means, incentive and punishment mechanism, information communication mechanism and supervision and implementation. Based on the survey data of 510 samples from 12 provinces in China, LI and JiANG (2015) investigated consumers' comprehensive evaluation of food safety including government departments, laws and regulations, and punitive measure. The results are shown in Table 1. Therefore, it is urgent to establish new regulations and improve the regulatory system in China (XIE \& TIAN, 2013).

\subsection{Prospects of dairy market in China}

China's growing demand for dairy products creates new market space. In view of the current dairy market situation, China should think about how to improve the quality of dairy products 
and win consumer confidence. Our research team believes that the following key points need to be seriously considered. First of all, the government regulation on dairy safety should be strengthened and international convergence of dairy standards should be emulated in time. Secondly, consumers' evaluation of the dairy market should be seriously considered by the government and enterprises. Third, the safety and quality of products should be improved by dairy enterprises, and advanced technology should be developed to improve the international competitiveness of dairy products.

Table 1. Consumer evaluation of government regulation

\begin{tabular}{lc}
\hline Evaluation & Proportion \\
\hline Government departments are unable to detect the quality and safety of dairy products & $34.31 \%$ \\
Current laws and regulations, testing technology cannot guarantee the quality of dairy products & $29.41 \%$ \\
The current punishment cannot effectively curb the illegal behaviour of manufacturers. & $32.35 \%$ \\
\hline
\end{tabular}

In short, the current dairy market in China calls for the strictest production standards, the strictest punishment, and strictest accountability. The government and enterprises have to ensure the healthy development of the dairy market and win consumers trust again.

\section{Conclusions}

This study shows that although more than a decade has passed since the dairy scandal in China, the negative impact has not been eliminated completely. It is mainly manifested in the fact that the domestic dairy market relies heavily on imports and unsatisfactory consumer evaluation. Chinese potential and the growing dairy market will continue to call for safe dairy products and effective government regulation, governments and enterprises should take social responsibility for food safety.

The results show that the lack of effective government regulation is a key reason for dairy market failure. Consumers still lack confidence in the quality of Chinese dairy products and government market supervision. Therefore, it is necessary to establish more strict dairy quality standards to reshape the image of the government and regain consumer confidence.

This research was supported by the National Natural Science Foundation of China No. 71573223 and also by Ministry of Education of the People's Republic of China No. 14YJA790003.

\section{References}

Beerepoot, M. \& BeERepoot, N. (2007): Government regulation as an impetus for innovation: Evidence from energy performance regulation in the Dutch residential building sector. Energ. Policy, 35, 4812-4825.

Brown, C.A., Jeong, K.S., Poppenga, R.H., Puschner, B., Miller, D.M., ... \& Brown, S.A. (2007): Outbreaks of renal failure associated with melamine and cyanuric acid in dogs and cats in 2004 and 2007. J. Vet. Diagn. Invest., 19, 525-531. 
Changquan, L., Lei, H. \& Yuanhong, Z. (2018): International comparison and development suggestions of China's dairy industry competitiveness. Chinese Rural Economy, 403, 132-146. (In Chinese)

China Association for Quality (2019): Survey results on consumer satisfaction of liquid milk industry in China, Available at: http://www.caq.org.cn/html/zyfw/zlsjk/4813.html (last accessed 12 September 2019) (in Chinese)

Cullor, J.S. (1997): HACCP (Hazard Analysis Critical Control Points): is it coming to the dairy? J. Dairy Sci., 80, 3449-3452.

Dairy Association of China (2018): China Dairy Yearbook 2017. China Agriculture Press, Beijing. 418 pages. (in Chinese)

Espejel, J., Fandos, C. \& Flavian, C. (2008): Consumer satisfaction: A key factor of consumer loyalty and buying intention of a PDO food product. Brit. Food J., 110, 865-881.

FAO (2019): Crops and livestock products, Available at: http://www.fao.org/faostat/en/\#data/TP (last accessed 25 August 2019)

Grunert, K.G. (2005): Food quality and safety: consumer perception and demand. Eur. Rev. Agric. Econ., 32, 369-391.

Hau, A.K.C., Kwan, T.H. \& Li, P.K.T. (2009): Melamine toxicity and the kidney. J. Am. Soc. Nephrol., 20, $245-250$.

HavelaAr, A., Grace, D. \& WU, F. (2019): Foodborne diseases from dairy products in developing countries. Hazards and health implications. Presentation at the 2019 annual meeting of the American Dairy Science Association, Cincinnati, Ohio, 23-26 June 2019. Gainesville, Florida (USA): University of Florida.

Hoppe, C., Mølgaard, C. \& Michaelsen, K.F. (2006): Cow's milk and linear growth in industrialized and developing countries. Annu. Rev. Nutr., 26, 131-173.

IngeLfinger, J. R. (2008): Melamine and the global implications of food contamination. New Engl. J. Med., 359, 2745-2748.

Lemaire, D. (2017): The stick: Regulation as a tool of government. -in: McCormick, J. (Ed.): Carrots, sticks and sermons, Routledge, New York, pp. 59-76.

LI, C. \& JiANG, B. (2015): Trust evaluation of dairy products quality safety in the perspective of situation and quality. Issues in Agricultural Economy, 3, 75-82. (In Chinese)

Major, G.C., Chaput, J.P., Ledoux, M., St-Pierre, S., Anderson, G.H., Zemel, M.B. \& Tremblay, A. (2008): Recent developments in calcium-related obesity research. Obes. Rev., 9, 428-445.

Martin-Shields, C.P. \& Stojetz, W. (2019): Food security and conflict: Empirical challenges and future opportunities for research and policy making on food security and conflict. World Dev., 119, 150-164.

National Standards of the People's Republic of China (2010): National Food Safety Standard. Good manufacturing practice for milk products, GB 12693 - 2010, Available at: http://cexgan.magrama.es/ MODULOS05/Documentos/Good_manufacturing_practice_for_milk_products.pdf last accessed?

Pei, X., Tandon, A., Alldrick, A., Giorgi, L., Huang, W. \& YAng, R. (2011): The China melamine milk scandal and its implications for food safety regulation. Food Policy, 36, 412-420.

Puschner, B., Poppenga, R.H., Lowenstine, L.J., Filigenzi, M.S. \& Pesavento, P.A. (2007): Assessment of melamine and cyanuric acid toxicity in cats. J. Vet. Diagn. Invest., 19, 616-624.

Schnettler, B., Ruiz, D., Sepúlveda, O. \& Sepúlveda, N. (2008): Importance of the country of origin in food consumption in a developing country. Food Qual. Prefer., 19, 372-382.

Schoder, D. \& McCulloch, C.R. (2019): Food fraud with melamine and global implications. -in: SMUlders, F.J.M., RietJens, I.M.C.M. \& Rose, M. (Eds) Chemical hazards in foods of animal origin, Wageningen Academic Publishers, pp. 543-565.

SHAO, Y. (2013): Rethinking food safety problems in China. Acta Alimentaria, 42, 124-132.

SHAO, Y. \& CAI, H. (2016): China food safety: Meeting the challenges of clenbuterol. Acta Alimentaria, 45, 331-337.

Wong, S.N. \& CHIU, M.C. (2008): The scare of melamine tainted milk products. Hong Kong J. Paediatr., 13, 230234.

XIE, Y.-M. \& TIAN, F. (2013): Regulations and guidelines should be strengthened urgently for re-evaluation on postmarketing medicines in China. Chin. J. Integr. Med. 19, 483-487.

ZHU, H. \& KANNAN, K. (2019): Occurrence of melamine and its derivatives in breast milk from the United States and its implications for exposure in infants. Environ. Sci. Technol., 53, 7859-7865. 